\title{
Culture Creative Industry Cluster Development Evaluation Index System Construction
}

\author{
Wang Yumei , Liu Shuyan, Wu Yongguo \\ Qingdao University of Science and Technology College of Economics and Management \\ Qingdao 266061 \\ Email:sixu1016@163.com
}

\begin{abstract}
Culture creative industry cluster is the enterprise agglomeration and cluster enterprise headquarters, the trading platform cluster and professional industrial chain form of enterprise cluster, is the creative planning products trade, industry research, works show, personnel training and exchange advice, etc organic combination of function. This paper from the nature, the humanities, services, capital, technology, intelligence dimensions of cultural creative industry cluster development evaluation index system. For cultural creative industry cluster quantitative evaluation index reference
\end{abstract}

Keywords- Culture creative industry cluster, Cluster, Development, Elements

\section{INTRODUCTION (HEADING 1)}

Science and technology revolution marked bay high-tech and related industry in the rapid development, it declared knowledge economic, cultural economy arrival. Culture creative industry is the product of knowledge economy of information age, is considered as the 21st century "sunrise industry", is the production subject of high-end cultural creative products. Culture creative industry cluster, is in the cultural creative industries in the field, there are numerous independent but related culture creative enterprise and related support mechanism, on the basis of the specialized division of labor and cooperation relations established, and in a certain area and the formation of agglomeration of industrial organization. The author thinks that, the real cultural industrial cluster is the enterprise agglomeration and cluster enterprise headquarters, the trading platform cluster and professional industrial chain form of enterprise cluster, is the creative planning products trade, industry research, works show, personnel training and exchange advice, etc organic combination of function. At present, cultural and creative industries cluster encounter a lot of problems in the process of the development, and how cultural and creative industries cluster rapid and sustainable development, has become the many scholars, entrepreneurs, the government is concerned about the topic. the cultural creative industry cluster in the process of development, met a lot of problems, the cultural creative industry cluster how to get rapid and sustainable development, has become a topic of concern by a number of academics, entrepreneurs, government.

\section{CULTURE CREATIVE INDUSTRY CLUSTER DEVELOPMENT INFLUENCE FACTORS ANALYSIS}

\section{A. Natural environment factor}

Historically, many cultural creative industry cluster were formed in places close to the rich natural resources.

(1) The degree of natural resources determines the degree of cultural reserves. The development of culture creative industry cluster needs a certain cultural resources and environment. A region's natural resources and environment determines the region's cultural reserve degree, and then affect the cultural creative industry cluster development degree.

(2) Habitat suitability. Natural climate and geographical environment can attract culture creative talents and enterprises come here and raise cultural creative activities.

(3) The natural landscape quantity. The more natural landscape quantity, can form aggregation effect and increase the cultural creative industry cluster appeal.

(4) The natural landscape attraction. The beautiful natural landscape, the higher level of fit with cultural creative industry cluster will increase its appeal.

(5) The level of urban greening. Greening can beautify the urban landscape, improve the living environment, absorption degradation city pollutants, reduce or eliminate urban heat island effect, purify atmospheric environment, reduce noise and so on, the city with high level of urban greening become a mark of urban cultural grade and civilization accomplishment.

(6) The degree of climate comfortable. Climate comfortable become an important factor to attract culture creative talents.

\section{B. Human elements}

(1) The total population. The total population point to overall scale of creative personnel. In a general meaning, the bigger of the total population scale, the higher the possibility of produce culture creative personnel.

(2) Population density. Population density can refer to the dense state of culture creative personnel.

(3) The number of public arts and cultural centers. It shows the level of regional public culture construction, and convenience degree of individual cultural consumption.

(4) Area folk brand quantity. Folk brand reveal region culture characteristic, the more number the easier to form cluster effect. 
(5) The attraction of area folk custom activity. Only accepted folk brand can be accepted by the public, folk activities appeal not only reflected in the local people attraction also reflected in the domestic and international public attraction and recognition.

(6) Cultural atmosphere. The cultural atmosphere is to point to the city's all kinds of cultural properties, including protection construction, local music, history and literary quotation, etc., some can't be copied and transplanted. In generally, culture creative industry cluster originated in this area's unique cultural heritage and atmosphere, and carries on the creative development and utilization.

\section{Capital elements}

(1) Expenditure of scientific and technological activities. The funds is raise from various channels and planed for creative activities, including government funds, enterprise funds, institution capital, financial institutions loans, foreign funds and other funds, etc.

(2) The external capital investment. External capital investment in two different conditions: The first is external industry affiliated enterprise moved in gathering area and forming division between enterprises. The second is the international industrial transfer, the multinational corporation invested and established joint venture, cooperation and wholly owned company and these companies formed division relations with industry cluster enterprises.

(3) The introduction level of risk investment. It reflects on the appeal of creative capital.

(4) The level of research and development funding. It refers to the research and development of the level of the fund investment of enterprises in the cluster.

(5) Culture creative talents learning cost level. It refers to the cost of industrial cluster staff training, learning, go out to study and communication, continue to take education courses.

\section{Technology elements}

(1) The number of science and technology activities personnel. Science and technology is the basic support for the cultural creative industry, the development of science and technology midwifery cultural and creative industries appear, the progress of science and technology provide inexhaustible motive force for the cultural creative industry development, without technology and science, creative industry is not expression. Science and technology activities personnel is who directly engaged in the science and technology activities, and specializing in science and technology activities management and provide direct service for culture creative activities. The index reflects the research and development ability of science and technology.

(2) The number of units of the research activities. Scientific research activity units provide intellectual support for the enterprises in cultural and creative industries cluster, the more quantity produced the more originality.

(3) The average annual number of patent license. It reflects original ability and the intellectual property rights popularity.

(4) The average annual number of creative produce. The more creative produce number that the more active thought.

\section{E. Interactive elements in a cluster enterprise}

(1) The division and specialization degree of cluster enterprises. Specialization is the most fundamental selforganizing power of cluster development, division and specialization of cluster enterprises is beneficial to form the division and cooperation power system.

(2) The degree of cooperation of industrial cluster. The higher level of cooperation the better for upstream and downstream enterprise develop in coordination.

(3) Level of trust within Clusters. Industrial cluster formed cooperation relation, and the relation base on trust and commitment, It is beneficial to the cluster stable and development.

Intelligence elements

(1) The number of ordinary graduates. The number of college graduation reflect the overall level of labor force and the quality of creative personnel. Each year, colleges transport all kinds of trained talents to the cultural creative industry cluster for it sustainable development.

(2) The number of universities. At present there is a certain type of cultural creative industry cluster area which is formed around universities where is rich human resources, this kind of park has advantageous location and resources advantages, the college influence and brand effect improve popularity of the creative park, such as Shanghai yangpu chifeng road city planning, architectural decoration design street is relying on the Tongji university civil construction professional talent technical advantage and gather up industrial base.

(3) The service level of universities and scientific research institutions. Culture creative industry cluster needs cooperation with external universities and scientific research institutions to get fresh originality, the service level provides sufficient follow-up support for the development of industrial clusters.

(4) The flexibility degree of labor market. Flexible labor market provides important protection for industrial cluster to use internal and external labor, in high flexible labor market, labor should be freely flow in different industries, occupation and geographic interval, free access to the labor market, it strengthens the vitality of the creative industry.

\section{CULTURE CREATIVE INDUSTRY CLUSTER} DEVELOPMENT EVALUATION INDEX SYSTEM CONSTRUCTION

According to above analysis of influence factors of natural environment, cultural, capital, the technical, industrial cluster interactive elements, intelligence, government affairs service and so on, the cultural creative industry cluster development evaluation index system with the nature, humanities, services, capital, technology, intelligence dimensions. As is shown in table 1.

TABLE I. CULTURAL CREATIVE INDUSTRY CLUSTER DEVELOPMENT EVALUATION INDEX SYSTEM

\begin{tabular}{|l|l|}
\hline \multicolumn{1}{|c|}{ One class index } & \multicolumn{1}{c|}{ Secondary indexes } \\
\hline \multirow{3}{*}{$\begin{array}{l}\text { Natural environment } \\
\text { factor }\end{array}$} & Cultural reserve level of natural resources \\
\cline { 2 - 2 } & \begin{tabular}{l} 
Habitat suitability \\
\cline { 2 - 2 } \\
Creative talents to the natural environment \\
approval
\end{tabular} \\
\hline
\end{tabular}




\begin{tabular}{|c|c|}
\hline & The degree of climate comfortable \\
\hline & Natural landscape quantity \\
\hline & The natural landscape attraction \\
\hline & $\begin{array}{l}\text { Geographical distance of the natural } \\
\text { landscape and industrial clusters }\end{array}$ \\
\hline & Urban greening level \\
\hline & The total population \\
\hline Human elements & Population density \\
\hline & The number of public arts and cultural centers \\
\hline & Area folk brand quantity \\
\hline & The attraction of area folk custom activity \\
\hline & The number of cultural heritage \\
\hline & $\begin{array}{l}\text { The number of cultural and creative industries } \\
\text { clusters }\end{array}$ \\
\hline & The degree of urban historical accumulation \\
\hline & Culture atmosphere \\
\hline Capital elements & $\begin{array}{l}\text { Expenditure of scientific and technological } \\
\text { activities }\end{array}$ \\
\hline & The external capital investment \\
\hline & The introduction level of risk investment \\
\hline & $\begin{array}{l}\text { The level of research and development } \\
\text { funding }\end{array}$ \\
\hline & Culture creative talents learning cost level \\
\hline & Creative purchase cost level \\
\hline & The level of creative product margins \\
\hline Technology elements & $\begin{array}{l}\text { The number of science and technology } \\
\text { activities personnel }\end{array}$ \\
\hline & The number of units of the research activities \\
\hline & The average annual number of patent license \\
\hline & $\begin{array}{l}\text { The average annual number of creative } \\
\text { produce }\end{array}$ \\
\hline & Success rate of creativity put into operation \\
\hline & Market competitiveness of creative product \\
\hline & Domestic leading level of creative \\
\hline & Efficient use of IT \\
\hline The interactive elements & $\begin{array}{l}\text { The division and specialization degree of } \\
\text { cluster enterprises }\end{array}$ \\
\hline in cluster enterprise & $\begin{array}{l}\text { The level of cooperation of enterprises in the } \\
\text { cluster }\end{array}$ \\
\hline & Level of trust within Clusters \\
\hline Intelligence factors & $\begin{array}{l}\text { Service level of universities and scientific } \\
\text { research institutions }\end{array}$ \\
\hline & Service level of Intermediary \\
\hline & Flexibility degree of labor market \\
\hline & Industry cluster knowledge learning ability \\
\hline & Policy support \\
\hline Government & Training policy \\
\hline service system & Planning guide \\
\hline & Infrastructure construction \\
\hline Facilities condition & Soft environment facilities construction \\
\hline & $\begin{array}{l}\text { Public products and service provision } \\
\end{array}$ \\
\hline
\end{tabular}

\section{CONCLUSION}

Culture creative industry is the product of information age of knowledge economy, is in the cultural creative industries in the field, there are numerous independent but related culture creative enterprise and related support mechanism, on the basis of the specialized division of labor and cooperation relations established, and in a certain area and the formation of agglomeration of industrial organization. Analyzes the impact factors from natural environmental factors, cultural factors, capital elements, technical elements, interactive elements of the enterprises in the cluster, intelligence elements, government services, and facility conditions, and gives the cultural creative industry cluster development evaluation index system with the nature, humanities, services, capital, technology, intelligence dimensions. Reference for the cultural and creative industries cluster quantitative evaluation.

\section{ACKNOWLEDGMENT}

This work was financially supported by the Shanghai University Science Foundation (J11WG10;), 2012 EI010.

\section{REFERENCES}

[1] Zhu dajian,Wang hongbing. Constructing Creative City -- - 2 l Century Shanghai Urban Development core value[J]. Journal of Urban Planning Journal of Urban Planning,2001,46(3):20-24p.

[2] John Howkins. The Creative Economy : How People Make Money from Ideas[M]. London : Penguin Books, 2002. 116

[3] Liu ying. Beijing Creative Industry Cluster Development Research[D]. Beijing University of Technology Degree Thesis.2008

[4] Wang ronghua. Shanghai Foster Tthe Development of Creative Industry's Exploration and Practice[M]. Shanghai: Shanghai Science And Technology Literature Press,2006.219

[5] Zeng guang,Zhang xiaoqing. The Characteristics of the Creative Industry Cluster and Its Development Strategy[J]. Science and Technology Management Research,2009(6),441,417-418

[6] Du debin,Sheng lei. Creative Lndustry: Modern Service Industry In the New Growth Point[J]. Economic Guide,2005(08):78.82.

[7] He shouchang. Creative Introduction to Learn[M]. Shanghai: Shanghai People's Publishing House,2006.5.. 